\title{
BHMT wt Allele
}

National Cancer Institute

\section{Source}

National Cancer Institute. BHMT wt Allele. NCI Thesaurus. Code C104870.

Human BHMT wild-type allele is located in the vicinity of $5 q 14.1$ and is approximately 21

$\mathrm{kb}$ in length. This allele, which encodes betaine-homocysteine S-methyltransferase 1

protein, plays a role in amino acid metabolism. 